Veronica Yepez-Reyes*

\title{
Connective Action for Global Fairness: Building Social Imaginaries
}

\begin{abstract}
Social imaginaries are frameworks within which people organise their collective world; where imagination, not simply reason, plays a part in the construction of social practices. Through a grounded theory approach, this article asks whether and how social imaginaries of global fairness are present in connective action, a type of digital interaction for advocacy. From January 2014 to June 2015, the study followed the Facebook accounts of five advocacy organisations: Hivos, Oxfam IBIS, Intermon-Oxfam, SSNC and Vredeseilanden. Connective action, more than just accomplishing an expressing function of posting and sharing - which could be considered as 'slacktivism'- denotes cooperating and acting by means of dialogic learning involving reflection and action. The research suggests that current social imaginaries may be built in connective action involving topics of nature conservation, equality, eco-farming, among others. Thus, the field of connective action remains open to theorizing how these imaginaries could constitute a strong foundation upon which communication for social change (CFSC) strategies may be grounded.
\end{abstract}

\section{Keywords}

connective action; communication for social change (CFSC); social imaginaries; global fairness; advocacy; digital interaction

\section{Introduction}

Advocacy identifies the expression of efforts, active interventions and actions engaged by a collective on behalf of a certain cause or political awareness. It is subject to a multiplicity of meanings, depending on the context and perspective from which advocacy is observed (Onyx et al. 2010, Reid 2000). Even though advocacy can be performed individually, it is in the collective action of like-minded people, working together and recognising the strength of the group, that advocacy organisations have been established. Nevertheless, advocacy's social imaginaries are also shared by a range of philanthropic activities and programs performed in corporate social responsibility initiatives (see e.g. Lee/Holladay 2017).

The notion of the 'social imaginary' was first coined by Greek-French philosopher Cornelius Castoriadis in the 1960s, referring not to something unreal or fictitious existing only in the mind of an individual, but to the shared frameworks within which people organise their collective social world (Castoriadis 1987). This notion has been revisited throughout time by different scholars. In 2009, political scientist Manfred Steger suggested the 'rise of the global imaginary', a step forward from Charles Taylor's (2004) 'modern imaginaries'. Inside the imaginaries of globalisation, Steger pointed out a full-blown ideology that was not "simply calling for an end to market-driven, neoliberal economic globalisation but is proposing a coherent global alternative to this model" (Steger/Wilson 2012: 452).

Building on the work of Steger et al. (2013) the focus of this study is on the presence of social imaginaries that illustrate a shared notion of global justice, which is termed global fairness. Fairness is considered a more accurate sense of the notion of justice to describe the current endeav-

\footnotetext{
* Veronica Yepez-Reyes, Ph.D.

Pontificia Universidad Catolica del Ecuador

Faculty of Communication, Linguistics and Literature | School of Communication

vyepezr@puce.edu.ec
} 
ours of society for advocacy. Fairness is less structural (laws and rules, and the administration of punishment and rewards) and more human and open to a global understanding of equality, solidarity, diversity, egalitarian participation and environmental responsibility.

\title{
Social Imaginaries and Social Movements for Social Change
}

According to Castoriadis (1987) social imaginaries mould societies, and give a specific orientation to them over a determined period. At the end of the $20^{\text {th }}$ century, the notion of the social imaginary acquired novelty in the work of a group of scholars researching "how globalization of culture and communication is transforming contemporary societies" (Gaonkar 2002: 2). Among them, the work of Canadian philosopher Charles Taylor proposed a concerted definition of the social imaginary:

\begin{abstract}
By social imaginary, I mean something much broader and deeper than the intellectual schemes people may entertain when they think about social reality in a disengaged mode. I am thinking, rather, of the ways people imagine their social existence, how they fit together with others, how things go on between them and their fellows, the expectations that are normally met, and the deeper normative notions and images that underlie these expectations. (Taylor 2004: 23)
\end{abstract}

Taylor's social imaginary was revisited by political scientist Manfred Steger and his group suggesting the rise of the global imaginary and within it, the emergence of alter-globalisation imaginaries led by social movement organisations (SMO), countering market-driven globalisation (Steger et al. 2013).

The alter-globalisation ideology (and not anti-globalisation as has been claimed by a number of scholars) is at the core of the Global Justice Movement (GJM) (Della Porta 2009, Funke 2012, Reitan 2012). The GJM, also called the 'movement of movements' or the 'network of networks', brings together a wide variety of social movements comprising individuals and organisations from gender to human rights, education, environment, food, and peace, among others, that interconnect with each other and spread their concerns in the global sphere.

The GJM and all the SMOs involved do not reject globalisation - quite the opposite - they value the affordances provided by communication and networking for advocacy purposes. It is in this landscape that the field of communication has a strategic role 'in shaping new models of society' (Martin-Barbero 2011) and to do so, it needs to consolidate the imaginaries of global fairness.

The ubiquitous presence of the media, the internet and ICTs make the leap from a mass media communication process, which established a relationship of one-to-many to a multi-way communication process of digital interaction. In 1998, Keck/Sikkink analysed how organisations built networks worldwide for advocacy purposes and termed them transnational advocacy organisations (TANs). The main idea behind TANs is that they are built to expand the advocacy scope on issues that are no longer just domestic, but have international repercussion in politics, world finances, trade and climate. TANs move in the logic of North-South relations and are a response from civil society to the growth of transnational corporations (Davies 2014).

This stage of connected advocacy could be referred to as a period of NGO-centred issue networks, targeting mainly governments and transnational economic agreements (Bennett 2005). The GJM started a second generation of advocacy in which SMOs make broad use of the affordances of the internet and ICTs for advocacy purposes. However, the 'internet age' (Castells 2013) also triggered new forms of advocacy which Bennett (2005) describes as forms of 'direct activism'.

SMOs have not been erased from advocacy in the global landscape, rather they have adopted new mechanisms relying on their technical strengths to accomplish global goals (see e.g. Ackland/O'Neil 2013, Cordoba/Jansen 2015). In 2012, Bennett/Segerberg suggested that even when connective action involves individualisation, there simultaneously also lies an organisational logic behind connected advocacy. In this way, they suggested that the 'logic of connective action' 
must be understood through three different types of networks: organisationally brokered collective action, organisationally enabled connective action and crowd-enabled connective action.

Currently, burgeoning literature focuses on 'crowd-enabled advocacy', which describes the performance of social movements of the 21 st century (see e.g. Toret 2013, Garcia-Albacete/Theocharis 2014). However, this study shares Bennett/Segerberg (2013: 48) notion that "organisationally enabled" connective action is "the most intriguing type" since it is a hybrid of the two other networked types. Studies in the field of communication related to advocacy, known as communication for social change (CFSC) share this centre, rooted on deliberative, participatory and transformative processes leading to social fairness.

According to Tufte (2013: 30) the field of CFSC "emerges from Freire's liberating pedagogy". The work of Brazilian pedagogue Paulo Freire from the 1960s broadly inspires the current CFSC, essentially highlighting the indissoluble links among communication, education and social change. Freire (2005) considers that dialogue is the essence of education, and education is an instrument for the practice of freedom because dialogue is only possible if it is filled up with words intended to transform reality and change the world. Dialogue is therefore considered a 'praxis' of reflection and action, which is only possible among committed people in a horizontal relationship. It is from this point of view that digital interaction in advocacy is analysed. CFSC, the current paradigm building on development, alternative and participatory communication, as proposed by Gumucio (2011: 32) is defined as "a process of dialogue and debate, based upon tolerance, respect, equity, social justice and active participation of all". These core concepts have a strong relationship with the categories analysed in the data of this study.

The understanding of communication as a tool for change (Marí Sáez 2012; Tarlau, 2014; Chaparro 2015; Tufte 2015) sustained on digital interaction - the multi-way communication process that is afforded by the internet and the use of ICTs - is fundamental to this study that aims to answer the questions of whether and how the social imaginaries of global fairness are present in digital interaction.

\section{Methodological and Empirical Considerations}

Trying to unpack the ways in which social imaginaries shape CFSC strategies presupposes a selection of particular kinds of organisations that enable participants in digital interaction to reflect and act towards shared viewpoints.

In this sense, a multiple-case design (Yin 2014) was proposed for the research including 'paradigmatic cases' (Flyvbjerg 2006) of interconnected advocacy organisations. Five European organisations with strong presence and performance on digital media were chosen; they all have a transnational scope and work in partnership with local organisations in different parts of the world as for example in Ecuador - homeland of the researcher studying in Denmark - to see how digital interaction takes place on a global scope with local peculiarities. To ensure language diversity, no two organisations with headquarters in the same European country were selected; diversity was also approached by including different sized organisations; and these organisations accepted to be part of the study.

The study analyses the discourses taking place from January 2014 to June 2015 in digital interaction on Facebook accounts of the following organisations: Hivos (the Netherlands - development humanist organisation), Oxfam IBIS (Denmark - development organisation engaged in quality education and public participation), Oxfam-Intermon (Spain - development organisation combating poverty and injustice), the Swedish Society for Nature Conservation (SSNC, Sweden - charitable environmental organisation) and Vredeseilanden (Belgium - development organisation contributing to viable livelihoods and empowerment of organised family farmers).

The histories of the organisations reveal that they all started as a result of "new social movements' (Della Porta 2009). Each became established as an organisation and widened their scope 
of action to become TANs (Keck/Sikkink 1998). However, nowadays it can be said that their 'activism has transformed digital' (Kavada 2010).

The analysis takes place within two different layers, one referring to the structure of digital interaction and the second, to the discourses and the actual content shared and constructed. The structure of digital interaction has been claimed to be rhizomatic (Yepez-Reyes 2017, Yepez-Reyes/Dohn 2016) by operationalising the 'metaphor of the rhizome' as a structure of thought (Deleuze/Guattari 1987). Digital interaction addresses multiple, diverse and scattered concerns, networks, and events, which are apparently disconnected, but in a broader context key concepts find linkages and emerge. Digital interaction also affords a multiplicity of languages to communicate simultaneously and asynchronously, which is otherwise unthinkable in face-to-face communication.

This paper focuses on the content of the discourses using the approach of grounded theory (Corbin/Strauss 2015) through a cyclical process of coding (Saldaña 2015). The data analysed was retrieved with the use of the CAQDAS (computer assisted qualitative data analysis) NVivo.

A challenge of the study has been to deal with a multiplicity of languages in the data collected from digital interaction, defined as the multi-way communication process mediated by the internet and the use of information and communication technologies (ICTs). The word fairness, and not justice, was chosen since fair is the precise sense of justice pointed out in the data from the Danish 'retfcerdig', the Swedish 'rättvisa' and the Dutch 'eerlijke'. The term 'fair' is also used for commerce that is socially just, environmentally sustainable and healthy for humans and for nature: 'fair trade'.

Despite the way the internet affords multi-modal discourses (including video, images, virtual world, sounds, etc.) this study analyses only textual interaction occurring in the Facebook accounts. Textual interaction refers to posts that trigger comment threads, building discourses, narratives, conversations and stories that may also split into other discourses, narratives, conversations and stories.

The total data retrieved was very extensive: 7,171 posts and 45,113 comments. For the analysis, a selection process took place based on the following sorting phases:

1. Posts with a higher number of comments, reactions and shares, which provided enough material to discuss the posts and trigger discourses.

2. Posts that refer to different events (only one instance of the same status update).

3. Posts relating to the concept of global fairness were preferred, understood in the way the SSNC frames the notion of '\#grönrättvisa' (\#greenfairness), which links environmental safe practices with human and moral fairness in a global scope.

4. Issues that, to some extent, related to Ecuador and the Andean Region were preferred, to see how global discourses could connect this country as well.

5. At least one post from a Facebook friend on the SMOs' timelines was also included. This is because comments on shared posts are as interesting as the ones on the SMOs' timeline since, as a post 'leaves' the SMO's page to be part of the timeline of a Facebook friend, it opens up the conversation to other networks in a new context (Oeldorf-Hirsch/ Sundar 2015).

Following these criteria, a total of 20 Facebook posts and their comment threads (3,617 postings) were analysed (see Table 1). The uneven distribution of posts analysed respond to the ways digital interaction took place on these pages. 
SSNC led enabled connective action on Facebook with $67.5 \%$ of posts displayed on its timeline by participants, followed by Oxfam Intermon with $52.1 \%$ and Hivos with $51.7 \%$. This is not to say they 'abandoned' their communication channels, rather these channels have been opened up as sites where participants had an opportunity to speak, reflect and debate. Bennett and Segerberg (2013) consider this as a 'digital mechanism' that personalises how individuals "engage in issues and causes that matter to the network actors" (2013: 48). Conversely, Hivos South America did not enable postings from others on its timeline, although it allowed comments on its own postings. The rate of enabled connective action in VECO Andino (7.1\%) and IBIS (14\%) were very low. Through Bennett and Segerberg's classification of networked connective action, VECO Andino, IBIS and Hivos South America could be considered to use Facebook "as means of mobilizing and managing participation and coordinating goals rather than inviting personalized interpretations of problems and action" (2013: 47). Participants were less eager to produce and generate new information but were prompted to discuss, share and comment on common collective frames provided by the organisation.

SSNC led a pattern of enabled connective action; at its page the number of comment threads on posts by Facebook friends was even higher than those on its own posts. In other words, the SSNC provided participants with a space in which many conversations took place and shared this space with their? friends in almost equal proportion (48\% against 52\%). The ratio of roughly 70 30 ( $70 \%$ own posts and $30 \%$ posts from friends) found on the Facebook accounts of Hivos, Redmanglar and Vredeseilanden showed a desire from these organisations to evolve their Facebook pages into spaces for connective action. While Oxfam Intermon's page was very active and its posts triggered huge comment threads (including an outstanding 979 comments on one post), the means by which participants were enabled to take part was much reduced (10\%). In general, digital interaction on Vredeseilanden's and VECO Andino's Facebook account was very limited with no visible dialogue, not providing enough material for analysis. Therefore, their posts were not included in the analysis.

\section{a) First coding cycle}

Digitally collected data - using NVivo, through its browser extension NCapture - was mined in Excel during the first coding cycle. Each comment was coded into one topic which was used afterwards to generate nodes in NVivo where all the mined data were re-imported for analysis. Coding at this stage consisted of a mixture of in vivo coding (literal use of expressions contained in the data) and 'descriptive coding' (concepts that explain the situation expressed). This kept a hierarchical relation within each post, managed separately from the rest. 154 different topics were coded from the 20 posts analysed (see Figure 1).

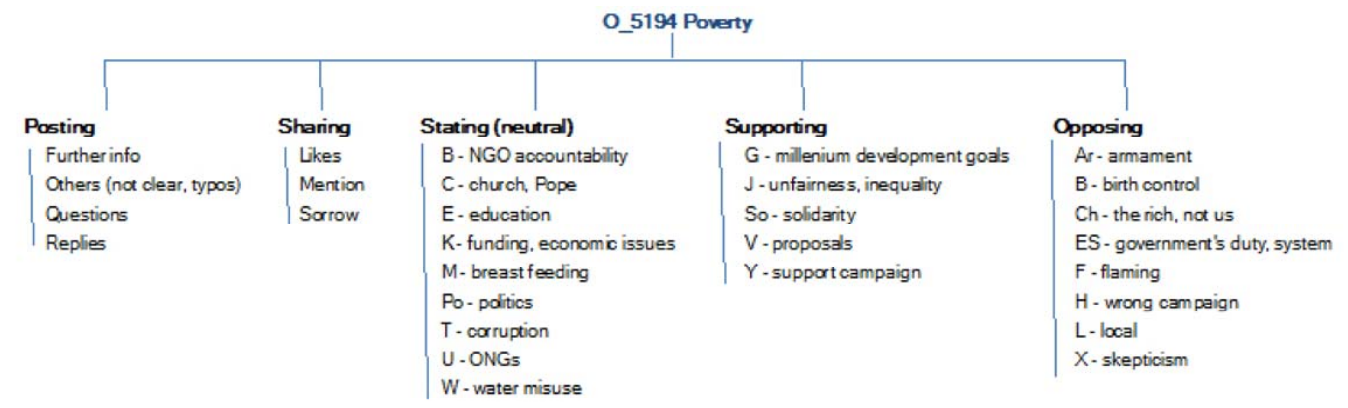

Figure 1. Nodes in NVivo from initial coding of post O_5194 
Table 1 Posts analysed

\begin{tabular}{|c|c|c|c|c|c|c|}
\hline SMO & Post *** & Likes & Comments & Threads & Shares & Topic \\
\hline \multirow[t]{4}{*}{ Hivos } & H_130 & 248 & 16 & 4 & 38 & fair trade roses \\
\hline & H_161 & 50 & 14 & 1 & 13 & support to development cooperation \\
\hline & H_240* & 42 & 9 & 0 & $\mathrm{n} / \mathrm{a}$ & cacao production \\
\hline & H_351 & 158 & 17 & 3 & 81 & child labour in fashion \\
\hline \multirow[t]{2}{*}{ Hivos South America } & SA_425 & 365 & 23 & 5 & 81 & women \\
\hline & SA_107** & 1011 & 343 & 21 & 172 & gay pride day \\
\hline \multirow[t]{4}{*}{ Oxfam IBIS } & I_902 & 9 & 128 & 19 & 2 & networking \\
\hline & I_311 & 810 & 166 & 47 & 520 & \#evenitup, extreme economic inequality \\
\hline & I_1437* & 38 & 25 & 0 & 0 & merging development and trade \\
\hline & I_o164 & 401 & 11 & 0 & 27 & Denmark 's efforts in Latin America \\
\hline \multirow[t]{2}{*}{ Oxfam_Intermon } & O_5194 & 34152 & 921 & 47 & 9892 & drinking water \\
\hline & O_9190 & 7377 & 171 & 3 & 959 & Robin Hood tax \\
\hline \multirow[t]{3}{*}{ Redmanglar Int. } & RM_1381 & 166 & 61 & 0 & $\mathrm{n} / \mathrm{a}$ & Zapoton forests, Chiapas \\
\hline & RM_1694 & 53 & 29 & 0 & 4 & biodiversity, Puerto Pizarro \\
\hline & RM_681 & 24 & 23 & 0 & 12 & mining project, Nicaragua \\
\hline \multirow[t]{5}{*}{ SSNC } & S_36577 & 24307 & 598 & 18 & 3868 & eko banana \\
\hline & S_16656 & 3122 & 438 & 69 & 2728 & \#grönrättvisa, death of cockle-gatherer \\
\hline & S_16205 & 5492 & 359 & 56 & 3744 & research against organic faming \\
\hline & S_16587* & 34 & 51 & 6 & $\mathrm{n} / \mathrm{a}$ & report $S_{-} 16205$ starvation \\
\hline & S_34187 & 5029 & 211 & 6 & 749 & räckbomba, shrimp consumption \\
\hline Total & 20 posts & 82,722 & 3,617 & 305 & 22,890 & \\
\hline
\end{tabular}

Table 1. Posts analysed

\section{b) Intermediate coding cycle}

In the first coding cycle, comments were entirely clustered into one category, namely the most salient from the narrative. However, a deeper analysis showed that many comments contained more than one topic; therefore, an intermediate coding cycle took place.

Below is an extract of a comment from the post 2015 Cacao Report on Chocolate Costs (H_240) to exemplify the intermediate coding cycle (Figure 2):

Trade agreements that encourage slave (labor) wages. And it's not going to improve

with Obama's signature (proposed) trade agreement the Trans Pacific Partnership fiasco,

that gives corporations veto power over sovereign countries (including US of course)

$i^{1}$

that may choose to protect workers, environmental concerns, etc, if those protections

cost corporations $\$$ to comply with. It ain't just chocolate!

$$
5
$$

$$
6 \quad \text { link to original post }
$$

Figure 2. Example of intermediate coding cycle in a comment 
Emerging categories were labelled either by in vivo coding or by process coding, i.e. coding that portrays the dynamics of digital interaction using action verbs stated as nouns, provided by the ing ending. The resulting coding for this extract is: 1) 'global trade agreements' 2) perceiving inequality, in its reference to 'slave labour' 3) feeling powerless 4) focusing on the local 5) 'grönrättvisa', SSNC's concept that brings together environmental, cultural and ethical fairness 6) 'costs' or economic issues.

This intermediate coding cycle allowed each comment to expand into the multiplicity of topics it actually contained which, to some extent, were hindered in the previous coding cycle that established fixed categories for the whole utterance. Thus, in this complex structure the aim was to determine which could be the major categories sustaining the social imaginaries of global fairness.

\section{c) Second coding cycle: focused coding}

Focused coding enables the rediscovery (or the recodification) of the content of comments in connection to others. Focusing on the previous codes, this last cycle enabled transferability and comparability. Major categories relating and connecting subcategories emerged as well as topics that enlarge and sustain this strength, as illustrated on the tree diagram of Figure 3.

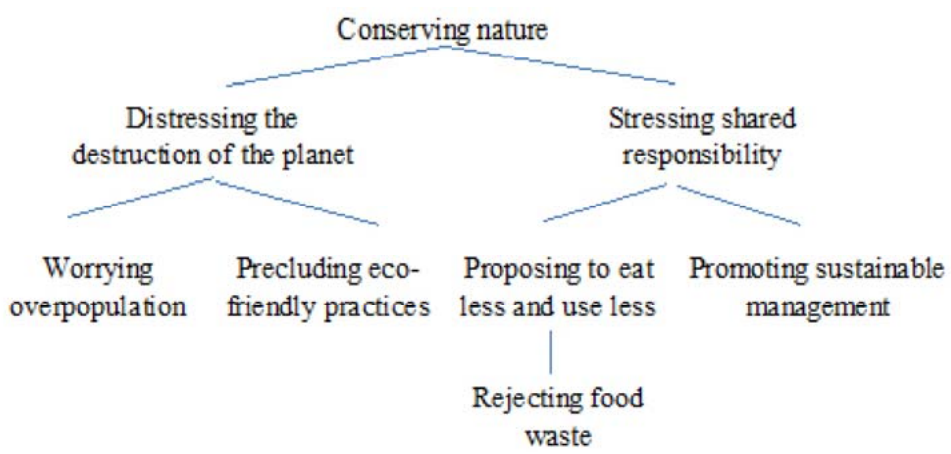

Figure 3. Conserving nature's tree diagram

\section{Results: Connective Action for Global Fairness}

Castoriadis (1987) describes as 'radical imaginary' the concrete forms in which social imaginaries are voiced. In an attempt to translate this concept to digital interaction, it could be said that the radical imaginaries of global fairness would be uttered and highlighted in postings.

The analysis of the way posts function in digital interaction led Shirky (2008: 49) to suggest three consecutive activities that "are enabled or improved by social tools": sharing, cooperation and collective action. While these activities are important, a step previous to sharing, namely posting - the action of imagining, creating and composing an update that is then shared - must not be forgotten.

Digital interaction does not require the co-presence, either in time or space, of participants but it does demand a first intellectual action of composing a meaningful text and posting it. Since no message exists in digital interaction before it is posted and becomes part of the sharing engine of the internet, the activities of posting and sharing are merged.

Shirky's last stage of 'collective action' is more clearly termed by Bennett/Segerberg (2013) as connective action. Following their 'logic of connective action' the authors make a distinction between collective action, in digital advocacy, which is organisationally brokered, and 'connective action', that is organisationally enabled, the type of action analysed in this study. 
Consequently, this multi-directional process of people communicating through posts mediated by the internet and the use of ICTs takes place through a dynamic cycle that involves four consecutive stages: posting, sharing, cooperating and acting, as shown on Figure 4.

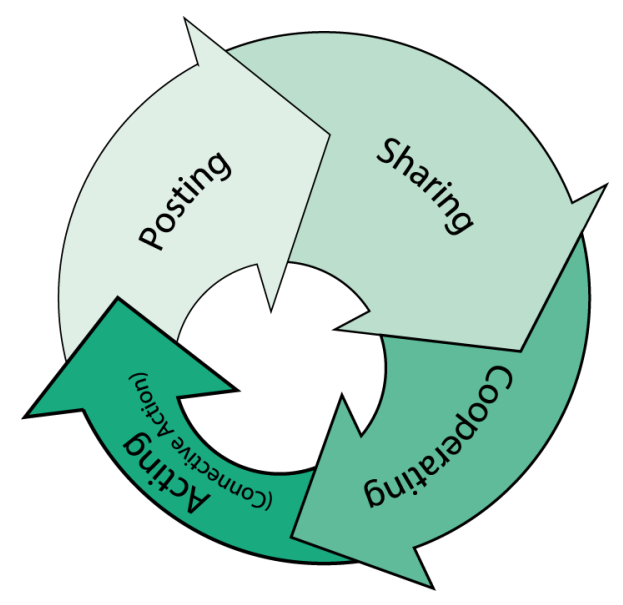

Figure 4. The cycle of digital interaction for advocacy ${ }^{1}$

This is an open-ended cycle that can start over and over again. Stages decrease in size and weight as they advance, since there is a difference both in how demanding and how much effort is required to move from one stage to the other. It can stop and restart at any of its stages, as illustrated in Figure 5.

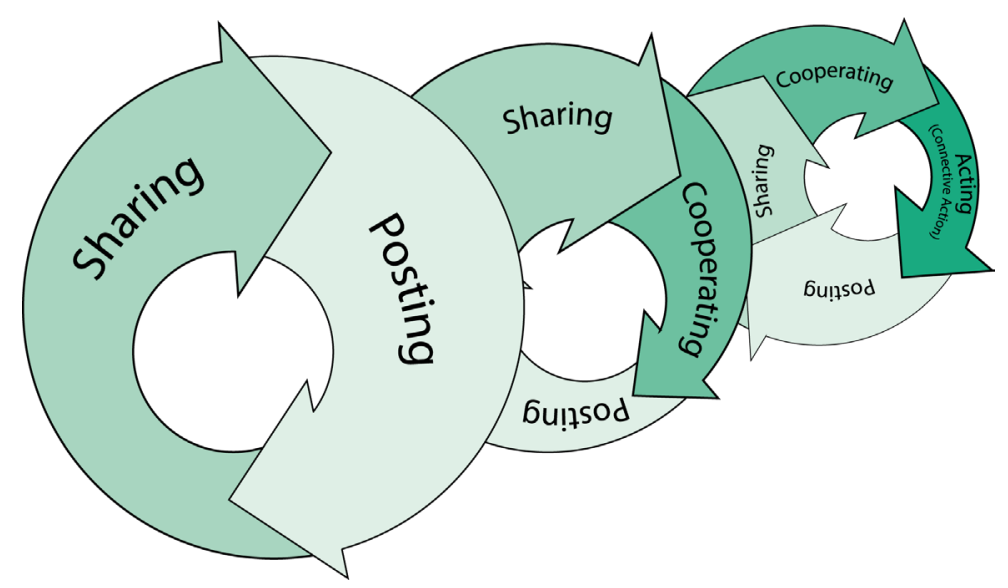

Figure 5. Development of the stages of the cycle of digital interaction for advocacy

\subsection{Stages of digital interaction}

\section{a) Posting}

A comment on a Facebook post, whether it is affirmative, negative, neutral or even distant to its content, is warranted both by the picture and the name of its owner, who intrinsically assumes the responsibility of his/her posting being displayed on the SMO's timeline. Marinucci (2010) refers to this as the 'Facebook effect', lacking the 'anonymity effect' that has been broadly associated with online communications. This is not to say that Facebook is free from fake profiles. However,

1 In the work of Bennett/Segerberg (2013) connective action is referenced under the fourth stage of acting, however acting can only be attained by following the three previous stages, as Figure 5 shows. 
the dynamics of Facebook and its networks prevents fake profiles from continuing undercovered with numerous examples of fake profiles whose real identity have been uncovered and have had unhappy endings, both legally and socially (Wellborn 2012).

Following the path of digital interaction, posting refers to comments, questions or direct replies that provide the same information contained in the main post that, through repetition, link to sites or other texts sharing the same information contained in the main post. While they do not add further information for discussion, they provide a sense of agency to the person who posts.

The example below (1) is from post I_311, which suggests that extreme economic inequality can be depicted with a bus where the $1 \%$ of the world richest can fit:

(1) 80 personer ejer mere end 3,5 mia fattige. De 80 rigeste mennesker $i$ verden ejer lige så meget som hele den fattigste halvdel af jordens befolkning. [link to dr.dk]

( 80 people own more than 3.5 billion poor people. The 80 richest people in the world own as much as the whole of the poorest half of the world's population. [link to dr.dk])

The text reproduces the headline of a news article on the website of the Danish Broadcasting Corporation (DR) and provides a link to it. It refers to precisely the same data contained in Oxfam IBIS's original post, which is the Danish version of Oxfam's International Campaign Even It Up.

However, the stage of posting in comment threads can also develop into the emergence of new lines of conversation popping up within the thread, without any apparent relation with the main post, as often happens in any type of conversation (face-to-face or mediated) taking the conversation in another direction.

\section{b) Sharing}

Sharing is the core concept that boosts the Web 2.0 and is fundamental for advocacy. In comments, sharing could be mainly of two types: 1) mentions to other users or that explicitly state their sharing nature, and 2) comments that react to the content expressing some type of emotion through words or emoticons, as with the use of the reaction buttons.

Some examples of comments focusing on shared expressivity rather than the provision of further information for discussion are provided below (2):

(2)

\begin{tabular}{|l|l|}
\hline Tankevcekkende!!! & Thought provoking!!! \\
\hline ja det er uhyggeligt:-)) & Yes it is scary :-)) \\
\hline $\begin{array}{l}\text { Kcemp for en verden hvor fä har for } \\
\text { meget og fcerre for lidt ;) }\end{array}$ & $\begin{array}{l}\text { Fight against a world where few } \\
\text { have too much and fewer too litt- } \\
\text { le ;) }\end{array}$ \\
\hline Det er jo forfcerdende... & It's appalling ... \\
\hline Carajo! & Damn! \\
\hline
\end{tabular}

In these examples, carajo, an expression of dislike in Spanish is included in this otherwise Danish comment thread, since digital interaction deals also with a multiplicity of languages.

\section{c) Cooperating}

Cooperating is regarded as a way of "changing your behaviour to synchronize with people who are changing their behaviour to synchronize with you" (Shirky 2008: 50). Comments move into the stage of cooperating when they reflect on the post, provide further information, provide clarification of terms in order to enhance dialogue or propose advocacy activities. Cooperating suggests dialogue, group work, negotiating and coordinating terms and ideas. 
The field of CFSC (Hemer/Tufte 2012, Tufte 2015) and specifically the domain of social movement learning (Hall et al. 2011, Langdon/Larweh 2015) points to informal learning processes built in dialogue combining reflection and action, as exemplified in the following comment:

(3) [mention to a friend] - här förklara dom rätt väl varför deras miljömärkning inte riktigt håller. Synd på en annars grym restaurang!:) alldeles för länge sen jag åt där, men tänker vänta tills dom slutat med scampin

([mention to a friend] Here they explain quite well why their eco-labels do not really work. Sad for an otherwise awesome restaurant :) long time since I ate there, but plan to wait until they end with scampi)

This comment, while directed to the mentioned friend, is displayed within the post thread, inviting others to read it and share the reflections about the proposed action. The comment addresses the action call and provides the SMO with support for the action. It also performs the desired goal to refrain from the consumption of cultivated giant shrimp (scampi), and displays a 'punishment' for this specific restaurant, which has lost a loyal client. In this way both reflection and action can be perceived.

\section{d) Acting}

Acting collectively and connectedly is the hardest stage to accomplish in this process as it supposes a commitment of the participants "in a way that makes the decision of the group binding on the individual members" (Shirky 2008: 51). This stage of connective action deals with the hybrid nature of online activism, where action can take place both online and off-line, but its purpose is to make a change to the off-line or physical world.

Connective action could emancipate participants from the dictum of 'slacktivism' (activism of the slacker) (Morozov 2011) by providing evidence of actual 'physical' participation in advocacy efforts. Nevertheless, it is always possible to say that talking and reflecting about an action carries no evidence of actual performance. However, it is also possible to think of social media as fostering accountability, since the networking nature of digital interaction leaves fewer possibilities for hoax engagement.

The following comments (4) are taken from the post on the campaign to 'shrimp bomb' a restaurant:

(4) Part.1 Jag mobbar dem varenda gång jag e där, påpekar förvånat att de fortfarande har skiten kvar [...] Givetvis, helt rätt att främst vända sig till de stora kedjorna först :)

\footnotetext{
(I bully them every time I am there, it is amazing that they still have the crap. [...] Of course, its absolutely right to address the big chains first :) )

Part.2 Part.1: om du påpekar det varje gång du är där, så är du där ofta? Då stödjer du ju dom ändå... ;) Det är inte Vapianos fel! Det är alltid konsumenten som bestämmer. Om ingen köper eller stödjer dem så försvinner räkorna från menyn! Konsumentkraft eller lagstiftning är de enda vägarna som fungerar!

(Part.1: if you point out that every time you are there, then you are there often? So you support them anyway ... ;) It's not Vapianos fault! It is always consumers that decide. If no one buys or supports them, then prawns disappear from the menu! Consumer Power or legislation is the only way that works! )
}

The first comment points to the individual's actual presence at the restaurant, which is remarked upon at the start of the second comment, which then focuses on market economics of supply and demand. This is not unusual, given how the action calls for a 'boycott' to the food chain - a consumers' practice to stop using certain businesses, encouraging them to change their operations. 


\subsection{Social imaginaries of global fairness}

Core categories in discourses emerge from the consecutive coding cycles applied. It is not that these categories are the only ones, nor are they the 'central' ones, as digital interaction for advocacy is not fixed nor centralised but multiple. Rather, these categories are the stronger ones at the moment.

The resulting major categories, which are made up of a number of subcategories, are: a) conserving nature b) stressing equality c) eco-farming d) globalising concerns e) trading f) assessing policy.

\section{a) Conserving nature}

Conserving nature deals with two main ideas: protection of the environment and human responsibility for its conservation. It reflects on the shift, contained in alter-globalisation imaginaries (Steger/Wilson 2012) and post-development approaches (Escobar 2008), from viewing humans as rulers of nature to locating humanity as part of the ecosystem through a sustainable management of its resources.

This can be exemplified with the comment below, on post S_16205, which stresses the importance of protecting the land and its biodiversity through sustainable management:

(5) Detta är iaf vad jag som bonde måste tänka på så jag tycker det är bara mer än rätt att alla andra som har åsikter om detta med markanvändning och vad som bör odlas också är med och tänker på jordens välbefinnande först, sen det antropocentriska så som vad vi tycker är rätt att äta eller inte.

\footnotetext{
(This is anyway what I as a farmer have to think about, so I think it's only fair that everyone who has an opinion on the land and what would be cultivated should also think on the Earth's well-being first, then the anthropocentric thought on what is right to eat or not.)
}

\section{b) Stressing equality}

The data tackles three different, though complementary, strains of equality: economic equality, gender equality and social equality. The dichotomy equality/inequality characterises this category. All posts struggle against different forms and levels of inequality, and this concept is so embedded in political discourses that the semantics of (in)equality has been studied "as vehicles for the emergence of a global imaginary" (Freistein 2014: 2)

For instance, the fight against extreme economic inequality is highlighted in the campaign Level it Up, contained in a post I_311. Economic inequality is also highlighted by Oxfam Intermon's fundraising post about providing drinking water to poor people (O_5194), by Hivos' post about child labour in fashion (H_351), by the SSNC's posts about shrimp farming (S_16656 and S_34187) and by IBIS's post about cooperation for development in Latin America (I_o164). In response to this last post, the following comment is made:

(6) En ulige fordeling af goderne set i et globalt perspektiv, men i lige så høj grad, en ekstrem ulige fordeling af goderne indenfor udviklinglandenes egne granser..

(An unequal distribution of wealth in a global perspective, but equally, an extremely unequal distribution of wealth within developing countries' own borders...)

In a similar vein to the above reflection, a number of comments concerned with unequal wealth distribution and poverty are made. This last topic gets entangled in both comment threads on Intermon Oxfam's page. Spain's context during the time of data collection was marked by the financial crisis. It is within this landscape that we see people refusing to take part in fundraising campaigns, labelling themselves as 'people in need':

(7) pero esto que es ?...y ahora venga a pedir a l@s que vivimos de una miseria. Y ademas sacamos algo de esa miseria para ayudar ....asco ne da 
(but what is this ?... asking for money to us that live in misery. And also get something out of that misery to help... it is disgusting)

The use of the @ in this post has become a common practice in social media in Spanish to avoid gender differentiation, the @ serves as a neutral gender creating a more inclusive discourse. In this case, it serves to address both women and men that 'live in misery'.

\section{c) Eco-farming}

SSNC's posts are all related in different ways to eco-farming. Eco-farming is also present in posts by IBIS, Hivos, Intermon Oxfam and SSNC's local partner Redmanglar Internacional, a Latin-American network advocating for mangrove indigenous communities (SSNC, 2011). The Swedish word ekologiskt or the Danish økologisk are both translated to mean 'organic' in English, which is also the term used in EU documentation ${ }^{2}$. Paradoxically, when translated into German this same documentation speaks both of biologische and ökologischer land production, illustrating the instability of competing terms.

The word 'organic' is mostly used to refer to a farming practice that avoids the use of chemicals and genetically modified organisms (GMOs). This is also part of ecological farming but ecological farming involves also sustainable diversified management (opposed to monoculture) and nature conservation. This distinction was a matter of debate in a thread on a post by the SSNC:

(8) Part.1: Ok, så ert exempel som skulle styrka att ekologiskt var bra visade sig inte vara ekologiskt utan agroekologiskt.

(Ok, so your example that would show evidence that organic was good turned out not to be organically BUT agroekologiskt.)

Naturskyddsföreningen Hej [Part.1], det är agroekologiskt jordbruk som utgår från ekologiska metoder. Läs gärna mer i denna rapport så får du en mer nyanserad bild: [link to report]

(Hi Part.1, it's agroecologic agriculture based on ecological methods. Please read more in this report to get a more nuanced picture: [link to report])

Part. 2 ... og ekologisk får aldri handle bare om hvordan vi gjödsler eller tar hånd om jord og vekster på större eller mindre monokulturer, men så klart også om å bevare artsrikdom i jordbruket og i jordbrukslandskapet/kulturlandskapet.

(... and ecological never refers to just about how we fertilize or take care of the land and crops in larger or smaller monocultures, but of course also about preserving species diversity in agriculture and in the agricultural landscape / cultural landscape)

The first comment challenges the information provided by the SSNC, which the organisation responds to, as do many other comments such as the comment shown in Part.2 (written in Norwegian, in a Swedish thread) explaining ecological farming.

\section{d) Globalising concerns}

'Globalising concerns' is the label used for grouping comments that explicitly suggest the global interrelation of issues, as for example these comments in SSNC's thread on eco-bananas:

(9) Part.1 Detta betalar iaf jag gärna för att arbetarna inte ska behöva vara i en besprutad miljö och så att barnen slipper få $i$ sig dessa gifter.

(This pays anyway I am happy that the workers should not have to be in a sprayed environment and that the children do not have to ingest these poisons.)

2 European Commission. Agriculture and Rural Development. Organic Farming. http://ec.europa.eu/agriculture/organic/eu-policy/eu-legislation/index_en.htm Retrieved 11.02.2016 
Part.2 Synd att dom "glömmer" dom som drabbas allra värst av kemikalierna nämligen arbetare på plantager. Produktionsförhållandena är enda anledningen att jag väljer ekologiskt.

(Too bad that they "forget" them as the foremost victims of the chemicals namely workers on plantations. The relations of production are the only reason that I choose ecologic.)

These comments are not connected in the comment thread. They refer to the extra cost of ecological bananas produced in Southern countries where 'the workers' live. There is a concern for the health of 'the workers' as well as for 'the children' who will consume these products, probably referring to children in Sweden.

\section{e) Trading and economic issues}

Trade and economy is another major category in the data. This category is deeply related to grönrättvisa as it includes many comments that deal with fair trade, focusing not only on conservation issues (which they also address), but on fair wages for producers and healthy products for consumers.

For example, Hivos' post on fair trade roses is not intended to promote any particular brand but suggests to choose fair trade flowers for Mother's Day. However, the post also opens up the possibility for other participants to promote their own businesses:

(10) Part.1 Eerlijk maar ook duurzaam natuurlijk [link to flower online shop]

(Fair but also durable naturally [link to flower online shop])

Part.2 Verras je moeder dit weekend met een prachtige bos eerlijke bloemen én een leuk jurkje van ?\#lejurk?!

(Surprise your mom this weekend with a beautiful bunch of fair flowers and a nice dress from? \#lejurk ?!)

The choice of the adverb 'naturally' in the text of the first comment is appropriate to emphasise the type of flower production offered by this group of retailers in the Netherlands. The second comment links to a second-hand shop of dresses that stress the notion of recycling. In this sense, both are connected to a notion of fairness and sustainable consumption.

\section{f) Assessing policy}

As politics is a major concern for SMOs, its presence in digital interaction is expected. Comment threads become spaces for expressing agreements and disagreements with the political system; the way governments address local problems and engage with global concerns. Perceived neo-colonialism practices are denounced as well as anti-democratic regimes and corrupt practices.

The financial crisis of 2014 provides the context for the posts on Intermón-Oxfam and, as a result, local policy is sharply assessed:

(11) A los españoles nos han visto cara de tontos, todo el mundo nos pide y nadie nos da, el gobierno nos pide sacrificios, los bancos dinero, los corruptos que miremos para otro lado, los empresarios que trabajemos por cuatro euros, y los partidos políticos que nos hagamos los tontos, hasta las esquinas están llenas de gente pidiéndonos y me pregunto cuando nos darán algo a nosotros

(They are relying on us, the foolish Spaniards, everyone asks us and nobody gives back, the government asks us to sacrifice, banks money, the corrupt to look the other way, entrepreneurs to work for four euros, and political parties that we become fools, every corner is filled with people pleading and wonder when they will give us something)

Comments such as the one above, showing a marked distrust for political parties and politics in general, are frequent in threads.

Since international cooperation between Europe and Ecuador was among the criteria for selecting these organisations, it is interesting to realise that the imaginary of policy in Southern coun- 
tries is mostly framed around corruption of the ruling class, which is emphasised in a number of comments. However, other comments point to corruption as a global issue:

(12) Part.1 Men bemoerk at de styrer og eliter ofte er holdt i live af udenlandske interesser pp bekostning af de fattige

(But note that the controllers and elites are often kept alive by foreign interests at the expense of the poor)

Part.2 ... du kan ikke inddele verden på den måde. Den korrupte elite du referer til er hverken særlig afrikansk, asiatisk eller noget som helst andet; den er international.

(... you can not divide the world in this way. The corrupt elite you refer to are neither particularly African, Asian or anything else; it is international.)

\section{Concluding Discussion}

The analysis of discourses within posts from SMOs points to most of the concepts contained in the imaginaries of alter-globalisation reflected by Steger et al. (2013) yet with subtle differences. Participants in digital interaction do not explicitly refer to universal rights - a major category in Steger's work - although issues involving economic, gender and cultural equality, and references to cases of perceived inequality, could point to a contained social imaginary of universal rights, expressed in terms of fairness at the different core categories suggested.

Participatory democracy, another category from Steger et al., is not spelled out in the discourses. Freistein (2014: 6) suggests "there is no easy heuristic that accounts for the causal relationship between equality/inequality and democracy, much less even on a global scale". This also applies to the data in this study where it can be suggested that the discourses about equality that are highlighted together with fairness, underlie participation and democracy.

Trading and economic issues are considered a major category in the discourses. This includes issues of fair trade where fair wages to producers, sustainability, nature conservation and health matters come together, as well as international trading agreements and treaties that are global in their scope. Hence, social imaginaries of the market and its prevailing presence in all activities are firmly part of the social imaginaries. But imaginaries of the market as an overruling power, or what Freire (2004: 25) describes as "democracy founded in the ethics of the market", are less present in the discourses analysed.

Ecological farming and nature conservation are core categories in the data. Describing as 'conventional' extensive industrial farming practices that differ greatly from ecological farming practices is an example of how social imaginaries have evolved. It is interesting to point out that industrial farming has acquired the attribute of conventionality and has thus become the ruling agricultural system in the current social imaginaries. As a result, proposals to dismantle this way of farming and move into ecological farming practices also require a dynamic change in the social imaginaries.

In the same vein, the core category of 'conserving nature' moves beyond the social imaginary of modernisation, in which forests, natural landscapes and wildlife were considered useless to production and wealth generation therefore justifying their radical transformation and extensive exploitation. The data points to social imaginaries that emphasise nature conservation and ecological farming practices for the benefit of the environment, which includes humans as part of the environment rather than separate from it.

SMOs play an important role in enabling their social media to provide participants with spaces for digital interaction, or better, for connective action. Notwithstanding the foregoing, just few SMO studied fully enabled connective action and not all participants, even in the enabled channels, partake in dialogue. This study has sought to be a state of the art analysis of the discipline of CFCS, focusing on SMO performing within the media ecologies of our time. It has provided 
some answers about the presence of social imaginaries of global fairness in digital interaction, though many questions remain.

Future research may lead to an understanding of the conditions needed for digital interaction to go beyond expressivity and enter into engagement and connective action that can lead to achieve social change. It may also lead to an understanding of how ICTs can enhance language diversity and multilingual conversations. Finally, it should contribute to identifying the pervasive social imaginaries that remain in conflict for the accomplishment of fairness on a global scale.

\section{Bibliography}

Ackland, Robert/O’Neil, Mathieu 2013: Online collective identity: The case of the environmental movement. In Hine (ed.), Virtual methods: issues in social research on the Internet. London: Sage, 239-272.

Bennett, W. Lance 2005: Social movements beyond borders: understanding two eras of transnational activism. In Della Porta/Tarrow (eds.), Transnational protest and global activism. Lanham, MD: Rowman \& Littlefield Publishers, 203-226.

Bennett, W. Lance/Segerberg, Alexandra 2013: The logic of connective action: digital media and the personalization of contentious politics, Cambridge studies in contentious politics. Cambridge: Cambridge University Press.

Castoriadis, Cornelius 1987: The Imaginary institution of society. Cambridge, UK: Polity Press.

Chaparro, Manuel 2015: Claves para repensar los medios y el mundo que habitamos. La distopia del desarrollo. Bogota: Ediciones desde abajo.

Corbin, Juliet M./Strauss, Anselm L. 2015: Basics of qualitative research: techniques and procedures for developing grounded theory. Los Angeles: SAGE.

Cordoba, Diana/Jansen, Kees 2015: Realigning the Political and the Technical: NGOs and the Politicization of Agrarian Development in Bolivia. In European Journal of Development Research advance online publication 19 March 2015.

Davies, Thomas Richard 2014: NGOs: a new history of transnational civil society. New York: Oxford University Press.

Deleuze, Gilles/Guattari, Felix 1987: A Thousand Plateaus. Translated by Massumi. Minneapolis: University of Minnesota Press.

Della Porta, Donatella 2009: Global Justice Movement Organisations: The Organisational Population. In Della Porta (ed.), Democracy in Social Movements. Basingstoke: Palgrave Macmillan Ltd, 16-43.

Escobar, Arturo 2008: Territories of difference: place, movements, life, redes, New ecologies for the twenty-first century. Durham: Duke University Press.

Flyvbjerg, Bent 2006: Five Misunderstandings About Case-Study Research In Qualitative Inquiry 12(2), 219-245.

Freire, Paulo 2005: Pedagogy of the Oppressed. Translated by Ramos. New York: The Continuum Intl. Publishing Group.

Freire, Paulo 2004: Pedagogy of indignation. Boulder, CO: Paradigm Publishers.

Freistein, Katja 2014: Are there any Global Imaginaries of Equality and Democracy in Discussions about Inequality? . In SFB 882 Working Paper Series, 38. Bielefeld: DFG: Research Center (SFB) 882.

Funke, Peter N. 2012: The Global Social Forum Rhizome: A Theoretical Framework. In Globalizations 9(3), 351-364.

Gaonkar, Dilip Parameshwar 2002: Toward New Imaginaries: An Introduction. In Public Culture 14(1), 1-19.

Garcia-Albacete, Gema/Theocharis, Yannis 2014: Opportunities and Challenges of Analysing Twitter Content: A Comparison of the Occupation Movements in Spain, Greece and the United States. In Cantijoch et al. (eds.), Analysing social media data and web networks. New York, NY; Houndmills, Basingstoke, Hampshire: Palgrave Macmillan, 119-153.

Gumucio Dagron, A. 2011: Comunicación para el cambio social: clave del desarrollo participativo. In Pereira, J. M./ Cadavid, A. (Eds.), Comunicación, desarrollo uy cambio social: interrelaciones entre comunicación, movimientos ciudadanos y medios. Bogotá: Pontificia Universidad Javeriana, 19-36.

Hall, Budd L./Clover, Darlene E./Crowther, J. I. M./Scandrett, Eurig 2011: Social movement learning: a contemporary re-examination. In Studies in the Education of Adults 43(2), 113-116.

Hemer, Oscar/Tufte, Thomas 2012: ComDev in the mediatized world. In Nordicom review (Special issue).

Kavada, Anastasia 2014: Transnational Civil Society and Social Movements. In Wilkins et al. (eds.), The handbook of development communication and social change. Chichester: John Wiley \& Sons, 351-369.

Keck, M./Sikkink, K. 1998: Activist Beyond Borders: advocacy networks in international politics. United States of America: Cornell University Press. 
Langdon, Jonathan/Larweh, Kofi 2015: Moving with the movement: Collaboratively building a participatory action research study of social movement learning in Ada, Ghana. In Action Research 13(3), 281-297.

Lee, Hen Ping/Holladay, Sherry J. 2017: Promoting Corporate Philanthropic Efforts through Social Media. HERMES Journal of Language and Communication in Business 25(49), 35-47.

Marí Sáez, V. 2012: Building knowledge from the margins: information, knowledge and social movements. In Transinformação 24, 61-64.

Marinucci, Mimi 2010: You Can't Front on Facebook. In Wittkower (ed.), Facebook and philosophy: what's on your mind? Chicago: Open Court, 65-74.

Martin-Barbero, Jesus 2011: From Latin America: Diversity, Globalization and Convergence. Westminster Papers in Communication and Culture 8(1), 39-64.

Morozov, Evgeny 2011: The net delusion: how not to liberate the world. London: Allen Lane.

Oeldorf-Hirsch, Anne/Sundar, S. Shyam 2015: Posting, commenting, and tagging: Effects of sharing news stories on Facebook. In Computers in Human Behavior 44, 240-249.

Onyx, Jenny/Armitage, Lisa/Dalton, Bronwen/Melville, Rose/Casey, John/Banks, Robin 2010: Advocacy with Gloves on: The 'Manners' of Strategy Used by Some Third Sector Organisations Undertaking Advocacy in NSW and Queensland. Voluntas: International Journal of Voluntary \& Nonprofit Organisations 21(1), 41-61.

Reid, Elizabeth J. 2000: Understanding the word 'advocacy': Context and use. Edited by Reid. 2 vols. Vol. 1, Structuring the inquiry into advocacy. Washington, DC: The Urban Institute.

Reitan, Ruth 2012: Theorizing and Engaging the Global Movement: From Anti-Globalization to Global Democratization. Globalizations 9(3), 323-335.

Saldaña, Johnny 2015: The coding manual for qualitative researchers. 3 ed. Los Angeles: SAGE.

Shirky, Clay 2008: Here comes everybody: the power of organizing without organisations. New York: Penguin Books.

Silverman, David 2013: Doing qualitative research. Los Angeles: Sage.

SSNC 2011: Murky waters. The environmental and social impacts of shrimp farming in Bangladesh and Ecuador. Retrieved from: http://www.naturskyddsforeningen.se/sites/default/files/dokument-media/murky_waters.pdf.

Steger, Manfred B./Goodman, James/Wilson, Erin K. 2013: Justice globalism: ideology, crises, policy. London, CA, New Delhi: Sage.

Steger, Manfred B./Wilson, Erin K. 2012: Anti-Globalization or Alter-Globalization? Mapping the Political Ideology of the Global Justice Movement 1. In International Studies Quarterly 56(3), 439-454.

Steger, Manfred B. 2009: The Rise of the Global Imaginary: Political Ideologies from the French Revolution to the Global War on Terror: Oxford University Press.

Tarlau, R. 2014: From a Language to a Theory of Resistance: Critical Pedagogy, the Limits of 'Framing', and Social Change. In Educational Theory, 64(4), 369-392. doi:10.1111/edth.12067

Taylor, Charles 2004: Modern Social Imaginaries, Public Planet Book. Durham \& London: Duke University Press.

Toret, Javier 2013: Tecnopolítica: la potencia de las multitudes conectadas. In IN3 Working Paper Series. Universitat Oberta de Catalunya: In3, Universitat Oberta de Catalunya.

Tufte, Thomas 2015: Comunicación para el cambio social. Spain: Icaria editorial.

Tufte, Thomas 2013: Towards a Renaissance in Communication for Social Change. In Tufte et al. (Eds.), Speaking up and talking back?: media, empowerment and civic engagement among East and Southern African youth. Göteborg: Nordicom,

Wellborn, Paul F., III 2012: 'Undercover teachers' beware: how that fake profile on Facebook could land you in the pokey. In Mercer Law Review 63(2), 697.

Yepez-Reyes, Veronica 2017: La Estructura Rizomática de la Incidencia 2.0. In Revista de la PUCE(104).

Yepez-Reyes, Veronica/Dohn, Nina Bonderup 2016: Affordances for læring i web 2.0: En rodvækstanalyse af kommunikation i organiserede sociale bevægelser. In Dohn/Hansen (Eds.), Didaktik, design og digitalisering. Samfundslitteratur, 175-196.

Yin, Robert K. 2014: Case study research: design and methods. 5th ed. London: Sage Publications. 